\title{
Genetic variation for virulence and RFLP markers in Pyrenophora teres
}

\author{
H.-L. Wu, B.J. Steffenson, Y. Li, A.E. Oleson, and S. Zhong
}

\begin{abstract}
Pyrenophora teres f. teres (causing net blotch) and Pyrenophora teres f. maculata (causing "spot form" of the disease) are important foliar pathogens of barley. In breeding for resistance to disease, it is important to have a thorough knowledge of the degree of genetic variation in the pathogen. This study was undertaken to assess genetic variation in a small, but geographically diverse collection of $P$. teres isolates. Isolates derived from single conidia were evaluated for their virulence phenotypes on 25 differential barley genotypes. Fifteen pathotypes were identified from a collection of $23 P$. $t$. f. teres isolates, and 4 pathotypes, from a collection of 8 P. $t$. f. maculata isolates. In general, the $P$. $t$. f. teres isolates exhibited a broader spectrum and a higher level of virulence on the host differentials than the $P$. $t$. f. maculata isolates. Eight barley genotypes were resistant to all 19 pathotypes identified and should be useful in breeding barley for resistance to both forms of P. teres. Genetic variation was also examined by restriction fragment length polymorphism (RFLP) analysis. A $0.46-\mathrm{kb}$ DNA fragment (ND218) generated by the polymerase chain reaction from genomic DNA of a California isolate of $P$. $t$. f. teres was used as a probe. Every $P$. teres isolate tested with ND218 exhibited a unique RFLP pattern. Cluster analysis, based on both the virulence phenotypes and RFLP patterns, indicates that $P$. teres possesses a high degree of diversity at the species and subspecies levels. The high degree of polymorphism revealed by ND218 will make this probe a useful tool for the DNA fingerprinting of $P$. teres isolates.
\end{abstract}

Key words: net blotch of barley, Pyrenophora teres, Hordeum vulgare, pathogen genetic diversity.

Résumé : Le Pyrenophora teres f. teres (responsable de la rayure réticulée) et le Pyrenophora teres f. maculata (responsable de la forme «tachetée » de la maladie) sont d'importants agents pathogènes des feuilles de l'orge. Lors de la sélection pour la résistance à la maladie, il est important d'avoir une connaissance approfondie du niveau de variation génétique de l'agent pathogène. Cette étude a été entreprise afin d'évaluer la variation génétique dans une petite, mais géographiquement variée, collection d'isolats de $P$. teres. Les phénotypes de virulence ont été déterminés pour des isolats issus de conidies uniques à l'aide de 25 génotypes différentiels d'orge. Quinze pathotypes ont été identifiés dans une collection de 23 isolats de $P$. $t$. f. teres, et 4 pathotypes, dans une collection de 8 isolats de $P$. $t$. f. maculata. En général, les isolats de $P$. $t$. f. teres avaient une gamme plus large et un niveau de virulence plus élevé sur les hôtes différentiels que les isolats de $P$. $t$. f. maculata. Huit génotypes d'orge étaient résistants aux 19 pathotypes identifiés et devraient être utiles en amélioration génétique de l'orge pour la résistance aux deux formes de $P$. teres. La variation génétique a aussi été étudiée par l'analyse du polymorphisme de la longueur des fragments de restriction (PLFR). Un fragment d'ADN de 0,46 kb (ND218) a été généré par réaction en chaîne de la polymérase à partir de l'ADN génomique d'un isolat californien de $P . t$. f. teres et a été utilisé comme sonde. Chaque isolat de $P$. teres analysé avec ND218 possédait son propre patron de PLFR. L'analyse typologique, basée à la fois sur les phénotypes de virulence et les patrons de PLFR, montre que le $P$. teres possède un niveau élevé de diversité tant pour l'espèce que pour les sous-espèces. Le niveau élevé de polymorphisme révélé par ND218 fera de cette sonde un outil utile de détermination d'empreintes génétiques d'ADN pour les isolats de P. teres.

Mots clés : rayure réticulée de l'orge, Pyrenophora teres, Hordeum vulgare, diversité génétique du pathogène.

Accepted 10 October 2002.

H.-L. Wu, B.J. Steffenson ${ }^{\mathbf{1}, 2}$, and S. Zhong. ${ }^{2}$ Department of Plant Pathology, North Dakota State University, Fargo, ND 58105, U.S.A.

Y. Li and A.E. Oleson. Department of Biochemistry, North Dakota State University, Fargo, ND 58105, U.S.A.

${ }^{1}$ Corresponding author (e-mail: bsteffen@umn.edu).

${ }^{2}$ Current address: Department of Plant Pathology, University of Minnesota, St. Paul, MN 55108, U.S.A. 


\section{Introduction}

Net blotch of barley (Hordeum vulgare L.), caused by the fungus Pyrenophora teres Drechs. f. teres Smedeg. [anamorph: Drechslera teres (Sacc.) Shoem. f. teres Smedeg.], is a common disease wherever the crop is grown (Mathre 1997; Shipton et al. 1973). The net blotch pathogen causes lesions that initially appear as spots and short yellow streaks on leaves. On susceptible genotypes, these infection sites expand into longer longitudinal and transverse necrotic streaks that produce a net-like pattern (Mathre 1997). Yield losses due to net blotch have been reported to range from 10 to $40 \%$ (Mathre 1997). In 1967, a different form of P. teres was described by McDonald (1967). This form, later designated as Pyrenophora teres Drechs. f. maculata Smedeg. (Smedegård-Petersen 1971), causes elliptical lesions that are distinctly different from the typical reticulate type caused by $P$. $t$. f. teres. Pyrenophora $t$. f. maculata is morphologically indistinguishable from $P$. $t$. f. teres and has been reported in many areas of the world (Mathre 1997). Yield losses due to this pathogen have been estimated at 10-20\% (Arabi et al. 1992; Karki and Sharp 1986).

When breeding barley for resistance to disease, it is important to have a thorough knowledge of the degree of genetic variation in the pathogen. Pyrenophora $t$. f. teres is known to vary in its virulence on barley, and distinct pathotypes have been reported from many production areas, including the Mediterranean region (Bockelman et al. 1983; Harrabi and Kamel 1990), North America (Singh 1962; Steffenson and Webster 1992), Australia (Khan and Boyd 1969), and Europe (Afanasenko and Levitin 1979; Smedegård-Petersen 1971). Variation for virulence has also been detected in $P$. $t$. f. maculata on barley (Bockelman et al. 1983; Karki and Sharp 1986; Khan 1982; Tekauz 1990; Tekauz and Mills 1974).

Virulence phenotypes can be useful for assessing genetic variation in fungal pathogens; however, virulence markers are often limited in number and subject to host selection (Leung et al. 1993), thus limiting their application in genetic variation studies. Molecular markers such as restriction fragment length polymorphism (RFLP), randomly amplified polymorphic DNA, and amplified fragment length polymorphism offer an alternate means by which genetic diversity can be measured in pathogens (Kohli et al. 1992; McDonald and Martinez 1990; Majer et al. 1996; Milgroom et al. 1992; Mueller et al. 1996; Peever and Milgroom 1994; Zhong and Steffenson 2001). Molecular markers have the advantage of being numerous and not subject to host selection. The objective of this study was to assess the genetic variation of a small, but geographically diverse collection of $P$. $t$. f. teres and $P$. $t$. f. maculata isolates, using both virulence and RFLP markers.

\section{Materials and methods}

\section{Fungal isolates}

Twenty-three isolates of $P$. $t$. f. teres and 8 isolates of $P$. $t$. f. maculata were evaluated for their virulence phenotypes. These isolates were from 12 different barley-growing regions of the world (Table 1) and represent a small, but diverse collection of $P$. teres isolates. All isolates were derived from single conidia taken from leaf tissue according to the method of Steffenson and Webster (1992). The cultures were maintained on silica gel at $4{ }^{\circ} \mathrm{C}$ until needed. Fifteen of $23 P . t$. f. teres isolates and 5 of $8 P$. $t$. f. maculata isolates were selected for RFLP analysis based on geographic origin. For comparison purposes with $P$. teres, three isolates of Pyrenophora graminea Ito \& Kuribayashi, one isolate of Pyrenophora tritici-repentis (Died.) Drechs., and three isolates of Cochliobolus sativus (Ito \& Kuribayashi) Drechs. ex Dastur, respectively, causal agents of leaf stripe on barley, tan spot on wheat, and spot blotch on barley, were also included in the RFLP analysis (Table 1).

\section{Assessment of virulence phenotypes}

Twenty-five differential barley genotypes were used for characterizing the virulence phenotypes of $P$. teres isolates (Table 2), 22 of which were previously used by Steffenson and Webster (1992) to investigate the virulence diversity of P. $t$. f. teres isolates from California. Lines ND B112 (CIho 11531) and FR 926-77 (no CI or PI number assigned) were also included in this study because they carry genes for resistance to $P$. $t$. f. teres, which are likely different from those already described (B.J. Steffenson, unpublished data). ND B112 was derived from the cross CIho 7117-77 $\times$ 'Kindred' (Wilcoxson et al. 1990), and FR 926-77 is a line developed by A.B. Schooler at North Dakota State University (Ceniceros 1990). Also included was 'Hector' (CIho 15514), a Canadian two-rowed cultivar developed from the cross 'Betzes' $\times$ 'Palliser', which is highly susceptible to many isolates of $P$. $t$. f. teres (B.J. Steffenson, unpublished data). Although this differential-host set was specifically selected for typing virulence in $P$. $t$. f. teres, it was thought to be sufficiently diverse and, therefore, useful for differentiating pathotypes of $P$. $t$. f. maculata.

Inoculum was prepared and applied as previously described (Steffenson et al. 1996). The infection phenotypes of isolates were assessed 10-14 days after inoculation, using the pictograph rating scales of Tekauz (1985) for $P$. $t$. f. teres and P. $t$. f. maculata. Only the central portions of the second leaves of plants were scored so as to avoid some of the atypical lesions that commonly occur on the leaf tips and edges. A disease reaction of 0 (immune) was included for leaves with no visible sign of infection. For $P$. $t$. f. teres, infection responses $0,1,2,3,4,5$, and combinations thereof were considered indicative of host resistance or a low infection response (LIR; i.e., low pathogen virulence) because the lesions remained restricted $(\leq 15 \mathrm{~mm}$ in length, $0.5-1.25 \mathrm{~mm}$ in width) in size and were associated with a limited amount of chlorosis, if present at all. Infection responses $6,7,8,9,10$, and combinations thereof were considered indicative of host susceptibility or a high infection response (HIR; i.e., high pathogen virulence) because the lesions were large ( $>15 \mathrm{~mm}$ in length, $>1.25 \mathrm{~mm}$ in width) and associated with extensive chlorosis. For $P$. $t$. f. maculata, infection responses from 1 to 5 and 7 to 9 [types 4 and 6 were not included in the scale of Tekauz (1985)] were considered indicative of LIRs and HIRs, respectively, according to the same criteria described for $P$. $t$. f. teres. All isolates were evaluated for their infection phenotypes at least two times, using a completely randomized design. Designations of pathotypes were based on the viru- 
Table 1. Fungal isolates tested for virulence phenotypes and restriction fragment length polymorphism.

\begin{tabular}{|c|c|c|c|}
\hline Isolate & Geographic origin & Source & Pathotype $^{\mathrm{a}}$ \\
\hline \multicolumn{4}{|c|}{ Pyrenophora teres f. teres } \\
\hline ISR3434 & Israel & R. Kenneth & $9-15-20$ \\
\hline MORZ-28 & Morocco & J.R. Burleigh & $0^{\mathrm{b}}$ \\
\hline UK80-12 & United Kingdom & V.W.L. Jordan & $22-25$ \\
\hline AUSKH565 & Australia & T.N. Khan & 0 \\
\hline WRS102-1 & Saskatchewan, Canada & A. Tekauz & $1-2-3-6-7-10-13-16-18-25$ \\
\hline NZ1A & New Zealand & J.E. Sheridan & $22-25$ \\
\hline MTSid84 & Montana, U.S.A. & H. Bockelman & $2-6-7-13-16-18-25$ \\
\hline MN1A & Minnesota, U.S.A. & R.D. Wilcoxson & $6-13-16-18-25$ \\
\hline CA86-79-1 & California, U.S.A. & B. Steffenson & $1-2-6-7-10-13-16-20-25$ \\
\hline CA84-28-1 & California, U.S.A. & B. Steffenson & $11-22-25$ \\
\hline CA86-21-1 & California, U.S.A. & B. Steffenson & $15-25$ \\
\hline CA86-57-1 & California, U.S.A. & B. Steffenson & $15-20-25$ \\
\hline CA84-8-2 & California, U.S.A. & B. Steffenson & 25 \\
\hline CA85-53-1 & California, U.S.A. & B. Steffenson & $3-10-15-19-21-25$ \\
\hline CA86-60-2 & California, U.S.A. & B. Steffenson & $3-10-15-19-20-21-25$ \\
\hline CA86-82-2 & California, U.S.A. & B. Steffenson & $20-25$ \\
\hline CA86-75-2 & California, U.S.A. & B. Steffenson & $15-20-25$ \\
\hline ND89-19 & North Dakota, U.S.A. & B. Steffenson & $1-2-6-7-10-13-16-18-25$ \\
\hline ND89-39 & North Dakota, U.S.A. & B. Steffenson & - \\
\hline \multicolumn{4}{|c|}{ Pyrenophora teres f. maculata } \\
\hline DEN2.7 & Denmark & V. Smedegård-Petersen & 0 \\
\hline DEN2.6 & Denmark & V. Smedegård-Petersen & $10-20$ \\
\hline DEN2.2 & Denmark & V. Smedegård-Petersen & 0 \\
\hline WRSAT82-67-3 & Manitoba, Canada & A. Tekauz & - \\
\hline CA90-1 & California, U.S.A. & B. Steffenson & - \\
\hline NOR3300 & Norway & H.A. Magnus & - \\
\hline \multicolumn{4}{|c|}{ Pyrenophora tritici-repentis } \\
\hline PTi-2T5 & North Dakota, U.S.A. & J. Jordahl & - \\
\hline \multicolumn{4}{|l|}{ Cochliobulus sativus } \\
\hline $\mathrm{ND} 85 \mathrm{~F}$ & North Dakota, U.S.A. & B. Steffenson & - \\
\hline ND89-33 & North Dakota, U.S.A. & B. Steffenson & - \\
\hline ND90Pr & North Dakota, U.S.A. & B. Steffenson & - \\
\hline
\end{tabular}

Note: A dash indicates missing or nonapplicable data.

${ }^{a}$ Pathotypes were determined based on the virulence phenotypes (LIR/HIR, low pathogen virulence/high pathogen virulence) of isolates on the 25 barley genotypes.

${ }^{\mathrm{b}}$ Mycelial fragments were used as inocula. For all other isolates, conidia were used as inocula.

lence phenotypes (LIR/HIR) of isolates on the 25 host genotypes (Table 2). The pathotype nomenclature follows the system described by Steffenson and Webster (1992). Each number in a pathotype designation corresponds to the numbered host genotype upon which that isolate is virulent (i.e., elicits an HIR) (Table 2). For example, a pathotype designated 15-20-25 indicates that this isolate is virulent on host genotypes of 'Prato' (No. 15), 'Cape' (No. 20), and 'Hector' (No. 25). Isolates exhibiting LIRs on all of the host genotypes were designated as pathotype 0 .

The relatedness of $P$. $t$. f. teres isolates was determined by analyzing their infection responses on host differentials using the PROC CLUSTER procedure from the SAS System (SAS Institute Inc. 1989). Similarity coefficients were 
generated using the quantitative city-block method with the following equation (Priestley et al. 1984):

$$
\left[\frac{1}{n} \sum_{j=1}^{n}\left(1-\frac{\left|X_{g j}-X_{k j}\right|}{R(j)}\right)\right\rfloor \times 100
$$

where $n$ is the total number of differential hosts $(n=25)$, $X_{g j}$ and $X_{k j}$ are the infection responses caused by isolates $g$ and $k$, respectively, on host genotype $j$, and $R$ is the range of infection responses, which is a function of the host genotype $j$, and varies from 0 to 10 .

In this study, individual host genotypes commonly displayed two (occasionally three) different infection responses to a pathogen isolate across replicates. For the cluster analysis, the most commonly observed infection response (i.e., the mode) was used. Values of the similarity coefficient lie within the range of 0 to 100 , where 0 indicates complete similarity and 100 represents complete dissimilarity. A phenogram was constructed based on this data set using the average linkage method (SAS Institute Inc. 1989).

\section{DNA isolation, Southern hybridization, and RFLP analysis}

Mycelium of the 20 individual isolates for RFLP analysis was harvested from $100 \mathrm{~mL}$ of liquid medium (glucose, $4.0 \mathrm{~g}$; peptone, $30 \mathrm{~g}$ (Difco, Sparks, Mich.); $\mathrm{K}_{2} \mathrm{HPO}_{4}, 1.0 \mathrm{~g}$; $\mathrm{MgSO}_{4} \cdot 7 \mathrm{H}_{2} \mathrm{O}, 0.5 \mathrm{~g} ; \mathrm{Fe}\left(\mathrm{NO}_{3}\right)_{2}, 0.447 \mathrm{mg} ; \mathrm{ZnSO}_{4}, 0.88 \mathrm{mg}$; $\mathrm{MnSO}_{4}, 0.4 \mathrm{mg}$; and double-distilled $\mathrm{H}_{2} \mathrm{O}$; for a final volume of $1.0 \mathrm{~L}) 5$ days after being inoculated with conidia and cultured with shaking at $22^{\circ} \mathrm{C}$. The 20 isolates were selected on the basis of geographic origin. Genomic DNA was isolated from lyophilized mycelium, using a method based on that of Murray et al. (1980), and digested with HindIII (New England Biolabs, Beverly, Mass.) in the reaction buffer as recommended by the manufacturer. Polymerase chain reaction was performed with genomic DNA templates from a California isolate of $P$. $t$. f. teres, using primers $\mathrm{Pt}-3$ (5'-ATGGATGCACGCAACGCTGC-3') and Pt-4 (5'-AGCTCCCTAAGCATAGCCCC-3') of Baltazar (1990). Four to seven amplification products, with sizes of $0.2-1.1 \mathrm{~kb}$, were obtained (Wu 1993). A 0.46-kb product from polymerase chain reaction was cloned and labeled by nick translation to provide a radioactive hybridization probe for RFLP analysis. Southern analysis and other DNA manipulations were carried out according to the methods of Sambrook et al. (1989).

Each autoradiogram from the RFLP experiments was scored for the presence (1) or absence (0) of a specific band for every fungal isolate. The equation of Nei and Li (1979),

$$
S=\frac{2 N_{x y}}{N_{x}}+N_{y}
$$

was used to generate similarity coefficients $(S)$. In this equation, $x$ and $y$ are the two isolates being compared, $N_{x y}$ is the number of RFLP bands shared by the two isolates, and $N_{x}$ and $N_{y}$ are the number of RFLP bands in each isolate. A phenogram was constructed with the NTSYS-pc program (Exeter Publishing, Setauket, N.Y.), using the un- weighted pair-group method with arithmetic averaging (UPGMA) from Dice similarity values. The validity of the resulting clusters was confirmed using the $\mathrm{COPH}$ and MXCOMP programs in the software package.

\section{Results}

\section{Assessment of the virulence phenotypes}

Fifteen pathotypes were identified from the $23 P$. $t$. f. teres isolates evaluated (Table 1). The mode and range of infection responses elicited by each isolate on the differential barley genotypes are given in Table 2. Pathotypes 1122-25 and 15-20-25 were most common, as each comprised $17.4 \%$ of the total number of isolates. Pathotypes 0, 22-25, 3-10-15-19-21-25, and 3-10-15-19-20-21-25 were the next most common and each comprised $8.7 \%$ of the isolates. The other pathotypes identified each comprised only $4.3 \%$ of the isolates. The most complex pathotype (i.e., with the broadest virulence spectrum) was 1-2-3-6-7-10-13-16-18-25 (isolate WRS102-1), which was virulent on 10 differential genotypes (Tables 1 and 2). Pathotypes 1-2-6-7-10-13-1620-25 (isolate CA86-79-1) and 1-2-6-7-10-13-16-18-25 (isolate ND89-19) were the next most complex, each exhibiting virulence on nine host genotypes. Virulence on 'Hector' and 'Cape' was common as 87 and $35 \%$ of the isolates, respectively, exhibited HIRs on these host genotypes (Table 2). 'Hector' was susceptible to all pathotypes, except pathotypes 0 (isolates MORZ-28 and AUSKH565) and 915-20 (isolate ISR3434). The host genotypes of 'Rojo', 'Coast', CIho 9819, CIho 5791, CIho 7584, CIho 5822, ND B112, and FR 926-77 were resistant to all of the pathotypes identified in this study.

The mode and range of infection responses elicited by $P$. $t$. f. maculata isolates on the differential barley genotypes are given in Table 3. Four pathotypes were identified from the eight isolates tested. Pathotype 0 (isolates DEN2.7, DEN2.2, DEN2.1, and AUSKH604) was most common, comprising $50 \%$ of the isolates, followed by pathotype $10-$ 20 (isolates DEN2.6 and WRS1049-1) at 25\% and pathotypes 20 (NOR1066) and 10-22 (NZKF2) at $12.5 \%$ each (Tables 1 and 3). Generally, the P. t. f. maculata isolates were less virulent than the $P . t$. f. teres isolates based on lesion size and the amount of associated chlorosis. Most of the differential barley genotypes were resistant to $P$. $t$. f. maculata with the exception of 'Kombar', 'Cape', and 'Rika', which were susceptible to some pathotypes.

From the cluster analysis of infection responses to $P$. $t$. f. teres, a phenogram was generated (Fig. 1). At a distance of $13.8 \%$ (equivalent to a $86.2 \%$ similarity level), the phenogram has three clusters. Cluster I (uppermost in Fig. 1) contains most of the California isolates (CA84-28-1, CA86-21-1, CA84-8-2, CA84-51-1, CA86-57-1, CA86-722, CA86-75-2, and CA86-82-2, with the latter five isolates being more closely related at a distance of 5.8\%), although one isolate each from the United Kingdom (UK80-12), Canada (WRS858-1), Australia (AUSKH565), New Zealand (NZ1A), and Israel (ISR3434) is also included in this cluster. Isolates representing pathotypes $0,25,15-25,20-25,22-$ $25,9-15-20,11-22-25$, and 15-20-25 were grouped in this cluster (Table 1). Isolates with virulence on 'Algerian', 
Table 2. Infection responses (mode/range) exhibited on 25 barley genotypes to 15 pathotypes of Pyrenophora teres f. teres differen-

$$
\text { Pathotype } \text { Pa }^{\text {Path }}
$$

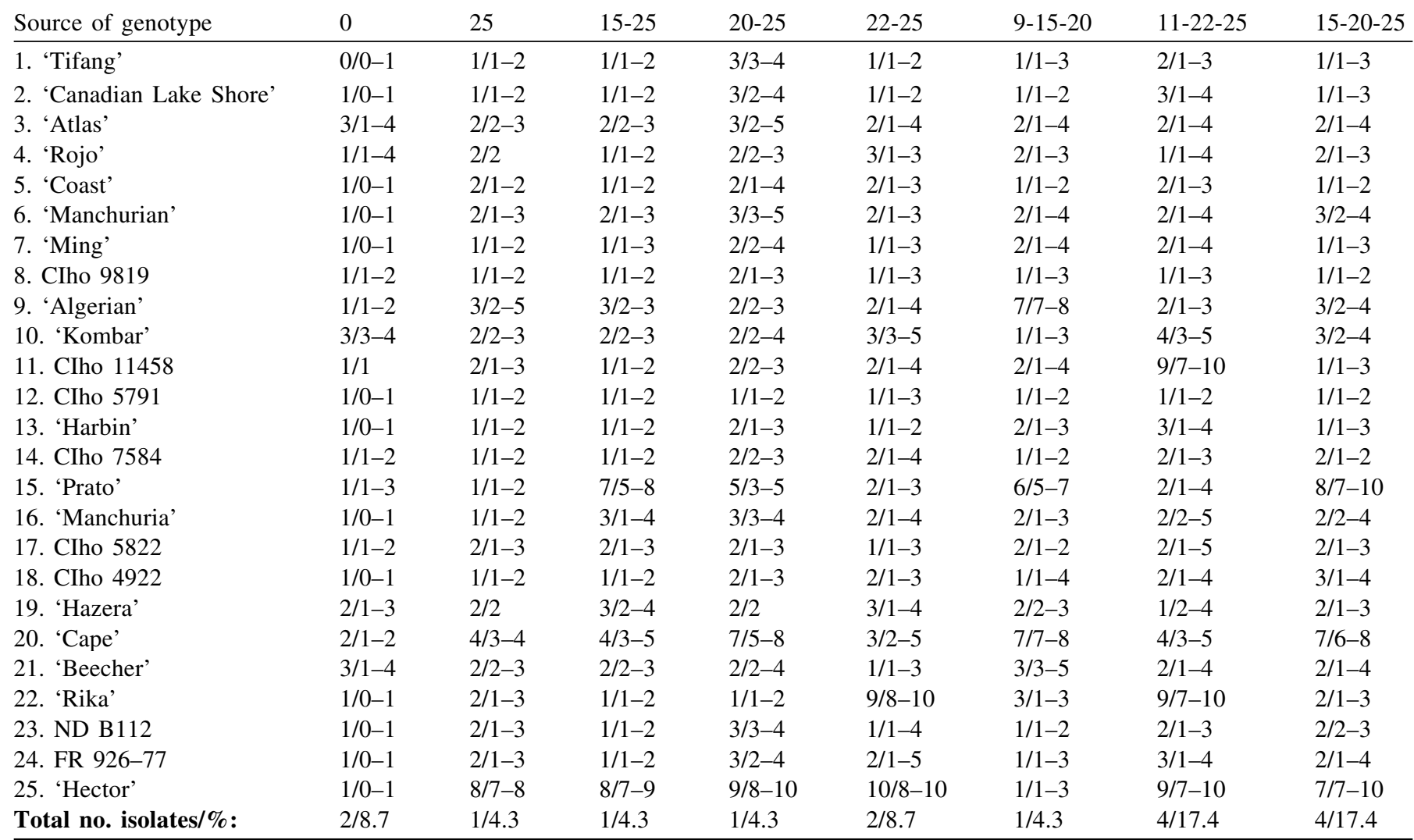

Note: The mode represents the most common infection response observed on the barley genotypes to isolates within a specific pathotype. The range

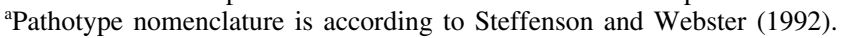

Fig. 1. Phenogram obtained by cluster analysis of the similarity matrix of infection responses from 23 isolates of Pyrenophora teres f. teres on 25 barley genotypes.

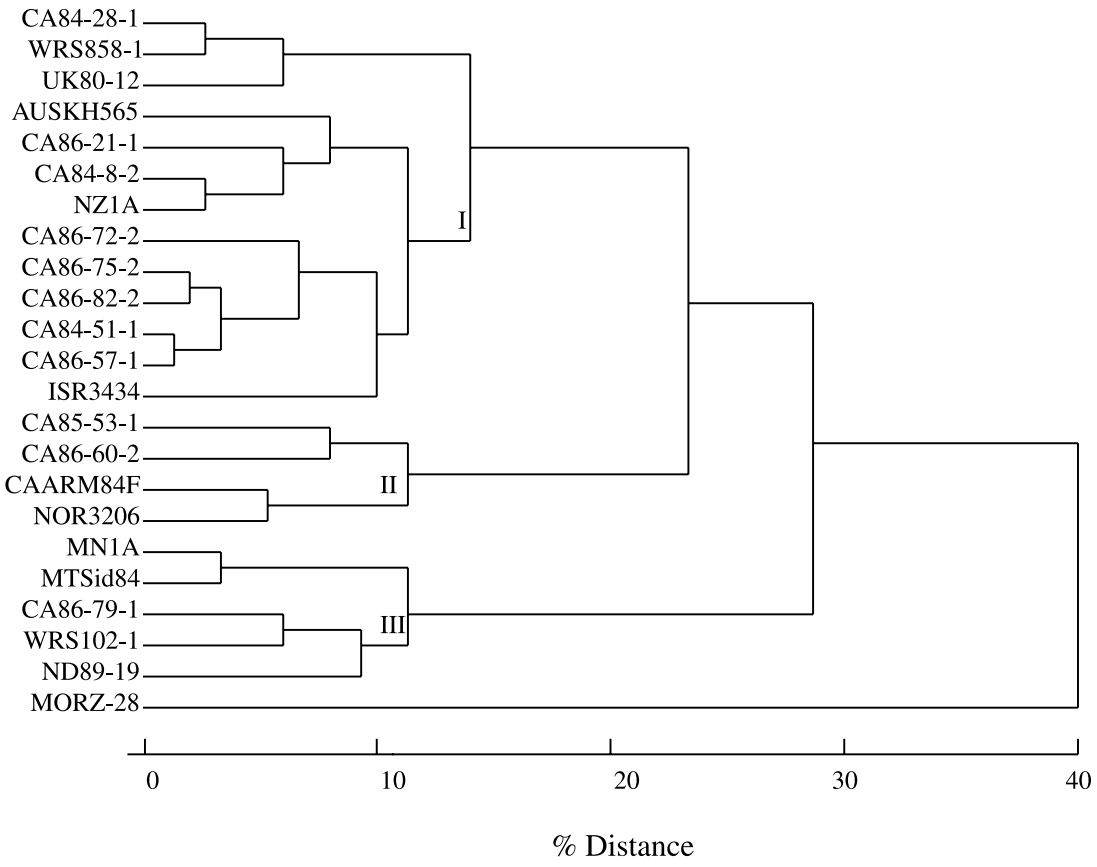


tiated from 23 isolates.

\begin{tabular}{|c|c|c|c|c|c|c|}
\hline $\begin{array}{l}6-13-16- \\
18-25 \\
\end{array}$ & $\begin{array}{l}3-10-15- \\
19-21-25\end{array}$ & $\begin{array}{l}2-6-7-13- \\
16-18-25 \\
\end{array}$ & $\begin{array}{l}3-10-15-19- \\
20-21-25\end{array}$ & $\begin{array}{l}1-2-6-7-10- \\
13-16-18-25\end{array}$ & $\begin{array}{l}1-2-6-7-10- \\
13-16-20-25\end{array}$ & $\begin{array}{l}1-2-3-6-7-10 \\
13-16-18-25\end{array}$ \\
\hline $3 / 3-5$ & $3 / 2-4$ & $7 / 7-9$ & $2 / 2-4$ & $8 / 8-10$ & $8 / 8-9$ & 9/9-10 \\
\hline $1 / 1-3$ & $9 / 9-10$ & $3 / 2-4$ & 9/9-10 & $4 / 3-5$ & $4 / 3-5$ & $7 / 6-8$ \\
\hline $1 / 1-2$ & $2 / 2-3$ & $2 / 1-2$ & $3 / 1-4$ & $2 / 1-3$ & $1 / 1-2$ & $1 / 1-2$ \\
\hline $1 / 1-3$ & $2 / 2-3$ & $8 / 7-9$ & $2 / 1-4$ & $7 / 7-10$ & 8/7-10 & $6 / 6-9$ \\
\hline $1 / 1-2$ & $1 / 1-3$ & $2 / 1-3$ & $1 / 1-2$ & $2 / 1-3$ & $1 / 1-3$ & $1 / 1-2$ \\
\hline $2 / 2-3$ & $2 / 2-4$ & $2 / 1-3$ & $3 / 2-3$ & $2 / 1-3$ & $2 / 1-3$ & $3 / 2-4$ \\
\hline $2 / 2-3$ & $9 / 7-10$ & $4 / 3-4$ & $8 / 7-10$ & $7 / 7-9$ & $6 / 5-8$ & $8 / 8-9$ \\
\hline $3 / 2-4$ & $1 / 1-3$ & $4 / 4-5$ & $2 / 2-4$ & $4 / 3-5$ & $4 / 4-5$ & $3 / 2-3$ \\
\hline $8 / 8-9$ & $4 / 3-4$ & $7 / 7-9$ & $2 / 2-5$ & $8 / 8-10$ & $8 / 8-10$ & $9 / 8-10$ \\
\hline $2 / 2-3$ & $2 / 1-4$ & $2 / 1-3$ & $2 / 1-3$ & $3 / 1-3$ & $2 / 1-3$ & $2 / 1-3$ \\
\hline $7 / 6-9$ & $3 / 3-5$ & $7 / 7-9$ & $2 / 2-4$ & 7/7-10 & $5 / 4-5$ & $8 / 8-9$ \\
\hline $2 / 1-3$ & $8 / 8-10$ & $2 / 2-3$ & $8 / 7-10$ & $4 / 4-5$ & $4 / 4-5$ & $4 / 3-6$ \\
\hline $4 / 3-5$ & $5 / 3-5$ & $4 / 3-5$ & $7 / 6-8$ & $5 / 4-5$ & 8/7-9 & $5 / 4-6$ \\
\hline $2 / 2-3$ & $10 / 8-10$ & $3 / 2-4$ & 8/7-10 & $3 / 3-5$ & $4 / 3-5$ & $5 / 4-6$ \\
\hline $3 / 3-4$ & $1 / 1-2$ & $3 / 2-4$ & $2 / 1-3$ & $4 / 3-4$ & $3 / 2-4$ & $2 / 1-3$ \\
\hline $2 / 1-2$ & $2 / 2-4$ & $2 / 2-4$ & $2 / 2-3$ & $3 / 3-4$ & $4 / 2-5$ & $3 / 2-4$ \\
\hline $2 / 2-4$ & $3 / 2-4$ & $2 / 1-3$ & $3 / 1-3$ & $3 / 3-5$ & $4 / 2-4$ & $3 / 2-4$ \\
\hline $10 / 8-10$ & $9 / 7-10$ & $9 / 9-10$ & $9 / 7-10$ & $10 / 8-10$ & $10 / 8-10$ & $10 / 9-10$ \\
\hline $1 / 4.3$ & $2 / 8.7$ & $1 / 4.3$ & $2 / 8.7$ & $1 / 4.3$ & $1 / 4.3$ & $1 / 4.3$ \\
\hline
\end{tabular}

represents the lowest and highest infection responses observed on the barley genotypes.

CIho 11458, and (or) 'Rika' were unique to this cluster. Cluster II (center in Fig. 1) consists of three California isolates (CA85-53-1, CA86-60-2, and CAARM84F) and one isolate from Norway (NOR3206). In this cluster, isolates comprising two similar pathotypes (3-10-15-19-21-25 and 3-10-15-19-20-21-25) were included. Isolates with virulence on 'Hazera' and 'Beecher' were unique to this cluster. Cluster III (bottom in Fig. 1) includes one isolate from each of the following locations: Minnesota (MN1A), Montana (MTSid84), California (CA86-79-1), Canada (WRS102-1), and North Dakota (ND89-19). Pathotypes with a relatively wide virulence spectrum (e.g., 6-13-16-18-25, 2-6-7-13-1618-25, 1-2-6-7-10-13-16-20-25, 1-2-6-7-10-13-16-18-25, and 1-2-3-6-7-10-13-16-18-25) were found in this cluster. Isolates with virulence on the host genotypes of 'Tifang', 'Canadian Lake Shore', 'Manchurian', 'Ming', 'Harbin', 'Manchuria', and (or) CIho 4922 were unique to this cluster. An isolate from Morocco (MORZ-28), designated as pathotype 0 , was not closely related to any of the above clusters at a distance of $39.5 \%$. No phenogram was constructed based on the virulence phenotypes of $P$. $t$. f. maculata because of the small number of isolates evaluated in the study and the general lack of diversity.

\section{RFLP analysis}

A high degree of DNA polymorphism was detected in $P$. $t$. f. teres and $P$. $t$. f. maculata when the clone ND218 was used as a probe for RFLP analysis. Up to six bands, with sizes of 1.1-14 kb, were resolved for isolates of $P$. $t$. f. teres, whereas a maximum of five bands, ranging from 4.2 to $11 \mathrm{~kb}$ in size, were resolved for isolates of $P$. $t$. f. maculata. Every isolate exhibited a unique RFLP pattern. The unique RFLP banding pattern of seven $P$. $t$. f. teres isolates and five P. t. f. maculata isolates is shown in Fig. 2.

No correlation was found between the virulence phenotypes (pathotype) of the isolates and the RFLP banding patterns. Several isolates, e.g., WRS858-1 (Canada) and CA8428-1 (California), were of the same pathotype (11-22-25, Table 1), but exhibited different RFLP patterns. In another such case, isolates CA86-79-1 (California) and ND89-19 (North Dakota) were very similar for virulence on the differential host genotypes (1-2-6-7-10-13-16-20-25 vs. 1-2-67-10-13-16-18-25); however, their RFLP profiles were distinct in that they only had a $3.7-\mathrm{kb}$ fragment in common among other polymorphic bands. Several isolates had a 4.7$\mathrm{kb}$ fragment in their RFLP profiles, but no correlation was found between the presence of this fragment and virulence on a specific host genotype.

From the combined cluster analysis of both $P$. $t$. f. teres and $P$. $t$. f. maculata (Fig. 3), three $P$. $t$. f. teres isolates from California (CA86-21-1, CA86-72-2, and CAARM84F) were found related at a similarity level of 0.63. CA86-21-1 and CA86-72-2 exhibited a higher level of similarity at 0.86 , as 
Table 3. Infection responses (mode/range) exhibited on 25 barley genotypes to four pathotypes of Pyrenophora teres f. maculata differentiated from eight isolates.

\begin{tabular}{|c|c|c|c|c|}
\hline \multirow[b]{2}{*}{ Source of genotype } & \multicolumn{4}{|c|}{ Pathotype $^{\mathrm{a}}$} \\
\hline & 0 & 20 & $10-20$ & $10-22$ \\
\hline 1. 'Tifang' & $1 / 0-3$ & $2 / 1-3$ & $2 / 2-5$ & $2 / 2-3$ \\
\hline 2. 'Canadian Lake Shore' & $3 / 3-5$ & $1 / 1-3$ & $2 / 2-5$ & $5 / 3-5$ \\
\hline 3. 'Atlas' & $2 / 2-3$ & $2 / 2-3$ & $2 / 2-5$ & $3 / 2-3$ \\
\hline 4. 'Rojo' & $1 / 1-3$ & $2 / 1-3$ & $2 / 2-3$ & $2 / 2$ \\
\hline 5. 'Coast' & $3 / 2-5$ & $3 / 2-3$ & $3 / 2-5$ & $3 / 2-5$ \\
\hline 6. 'Manchurian' & $2 / 2-5$ & $2 / 1-3$ & $3 / 2-5$ & $3 / 2-5$ \\
\hline 7. 'Ming' & $2 / 1-5$ & $2 / 1-3$ & $3 / 2-5$ & $3 / 2-3$ \\
\hline 8. CIho 9819 & $3 / 2-5$ & $3 / 2-5$ & $3 / 2-5$ & $5 / 3-5$ \\
\hline 9. 'Algerian' & $2 / 2-5$ & $3 / 2-3$ & $3 / 2-5$ & $3 / 3-5$ \\
\hline 10. 'Kombar' & $2 / 2-3$ & $3 / 3-7$ & $7 / 5-8$ & $8 / 7-9$ \\
\hline 11. CIho 11458 & $1 / 1-2$ & $5 / 3-5$ & $5 / 3-5$ & $5 / 5-7$ \\
\hline 12. CIho 5791 & $1 / 1-2$ & $3 / 2-5$ & $5 / 3-5$ & $5 / 5-7$ \\
\hline 13. 'Harbin' & $2 / 2-5$ & $2 / 2-3$ & $3 / 2-5$ & $3 / 2-5$ \\
\hline 14. CIho 7584 & $3 / 1-5$ & $3 / 2-3$ & $3 / 2-5$ & $3 / 2-3$ \\
\hline 15. 'Prato' & $3 / 2-5$ & $3 / 3-5$ & $5 / 3-5$ & $5 / 5-7$ \\
\hline 16. 'Manchuria' & $3 / 1-5$ & $2 / 1-2$ & $2 / 1-3$ & $3 / 2-3$ \\
\hline 17. CIho 5822 & $3 / 1-5$ & $5 / 3-7$ & $5 / 3-5$ & $5 / 5-7$ \\
\hline 18. CIho 4922 & $3 / 3-5$ & $2 / 2-3$ & $3 / 2-3$ & $3 / 3-5$ \\
\hline 19. 'Hazera' & $3 / 2-5$ & $5 / 5-7$ & $3 / 3-5$ & $5 / 5-7$ \\
\hline 20. 'Cape' & $3 / 3-5$ & $7 / 5-7$ & $7 / 5-8$ & $5 / 5-7$ \\
\hline 21. 'Beecher' & $3 / 3-5$ & $5 / 3-7$ & $5 / 2-5$ & $5 / 3-5$ \\
\hline 22. 'Rika' & $2 / 1-5$ & $5 / 3-5$ & $5 / 3-7$ & $7 / 5-8$ \\
\hline 23. ND B112 & $2 / 1-3$ & $3 / 2-5$ & $3 / 3-5$ & $3 / 3-5$ \\
\hline 24. FR 926-77 & $2 / 1-3$ & $2 / 1-3$ & $2 / 2-3$ & $3 / 2-5$ \\
\hline 25. 'Hector' & $2 / 1-5$ & $2 / 2-3$ & $3 / 2-3$ & $3 / 3-5$ \\
\hline Total no. isolates $/ \%$ : & $4 / 50$ & $1 / 12.5$ & $2 / 25$ & $1 / 12.5$ \\
\hline
\end{tabular}

Note: The mode represents the most common infection response observed on the barley genotypes to isolates within a specific pathotype. The range represents the lowest and highest infection responses observed on the barley genotypes.

a Pathotype nomenclature is according to Steffenson and Webster (1992).

Fig. 2. Autoradiograms of restricted Pyrenophora teres f. teres and Pyrenophora teres f. maculata DNA hybridized to the radiolabeled probe ND218. 1, molecular size marker; 2, CA8621-1; 3, MTSid84; 4, WRS102-1; 5, ISR3434; 6, MORZ-28; 7, CAARM84F; 8, CA86-79-1; 9, DEN2.7; 10, NZ2A; 11, NZKF2; 12, AUSKH604; 13, DEN2.1. Sizes of fragments are expressed in kilobases.

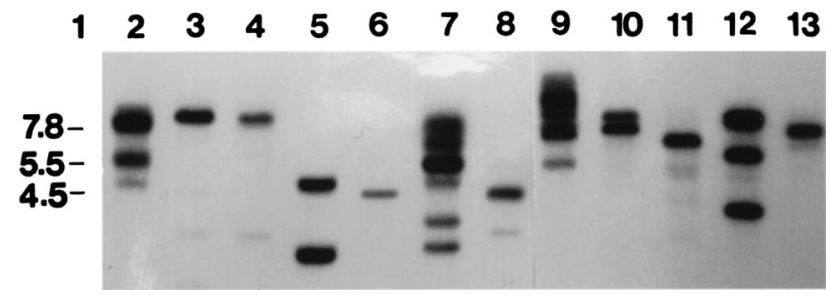

they had three bands in common and only one band unique. Isolates MTSid84 (Montana) and WRS102-1 (Canada), DEN2.1 (Denmark) and NZ2A (New Zealand), WRS858-1 (Canada) and AUSKH604 (Australia), and AUSKH565 (Australia) and UK80-12 (United Kingdom) clustered in pairs at a similarity level of 0.67 . Minnesota isolate MN1A was related to California isolates CA86-21-1, CA86-72-2, and CAARM84F at a similarity level of 0.59, while California isolate CA84-28-1 was related to Australian isolate
Fig. 3. Phenogram obtained by cluster analysis of the similarity matrix of restriction fragment length polymorphism from 15 isolates of Pyrenophora teres f. teres (T) and 5 isolates of Pyrenophora teres f. maculata (M).

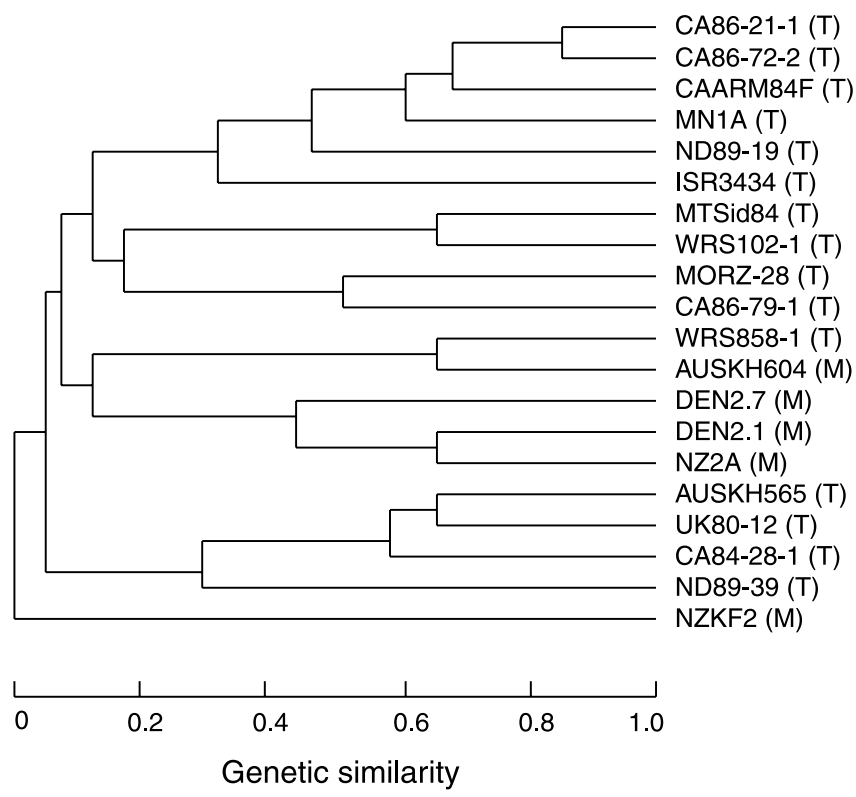


AUSKH565 and United Kingdom isolate UK80-12 at a similarity level of 0.58 . Three $P$. $t$. f. maculata isolates (DEN2.1 and DEN2.7 from Denmark and NZ2A from New Zealand) clustered together at a similarity level of 0.43 , but other $P$. $t$. f. maculata isolates did not form distinct groups from other $P$. $t$. f. teres isolates. Generally, the 20 P. teres isolates evaluated were not closely related since most similarity coefficients ranged from 0 to 0.67 .

Of the three isolates of $P$. graminea that were tested for RFLP, only one (WRSAT82-67-3) hybridized to the probe ND218. This isolate gave a faint $2.8-\mathrm{kb}$ band (data not shown). The one $P$. tritici-repentis isolate (PTi-2T5) tested hybridized weakly to probe ND218, giving three faint bands of $3.0,4.5$, and $7.0 \mathrm{~kb}$ (data not shown). Of the three C. sativus isolates evaluated, only one (ND89-33) hybridized to probe ND218. This isolate gave bands of 4.0 and $4.5 \mathrm{~kb}$ in size, the former being unique to this particular isolate (data not shown).

\section{Discussion}

The P. $t$. f. maculata isolates did not possess a broad virulence spectrum on the differential set developed originally for $P$. $t$. f. teres, since the greatest number of host genotypes upon which any isolate exhibited a HIR was three. It is possible that other host genotypes would be more suitable for detecting virulence polymorphisms in this pathogen, but this aspect must be investigated further. Alternatively, $P$. $t$. f. maculata may simply not possess the virulence spectrum that has evolved in $P . t$. f. teres. Pyrenophora teres f. maculata was generally less virulent than $P$. $t$. f. teres, since only a few isolates exhibited infection responses greater than 7 (Table 3 ). This is in contrast to $P$. $t$. f. teres where many isolates exhibited infection responses greater than 7 (Table 2). This result is in agreement with a previous study by Tekauz and Mills (1974).

From the phenogram based on infection responses to $P$. $t$. f. teres, it was difficult to make any salient generalizations regarding the possible relationships of isolates from different geographic regions. Isolates from Minnesota (MNlA), North Dakota (ND89-19), Montana (MTSid84), and Saskatchewan, Canada (WRS102-1) clustered together based on their infection responses (Fig. 1), indicating a closer relatedness among the isolates that were collected in the north central part of North America. It is possible that these isolates were from the same genetic pool of virulence phenotypes. Populations of $P$. teres may not remain geographically isolated for a long time because exchanges of seed infected with $P$. teres over different areas can occur. In contrast to the few isolates from a single region that clustered together, the California isolates were dispersed in every cluster. The majority of these isolates, however, were in cluster I (Fig. 1). Gene flow between and among local populations could be responsible for the random dispersal of diverse virulence phenotypes (Peever and Milgroom 1994; Slatkin 1987). Although the isolates tested in this study were from diverse geographic regions, the sample number was very small. It is therefore difficult to draw any firm conclusions regarding the genetic structure of the pathogen population. A comprehensive population genetic study of $P$. teres is warranted. For such an investigation, it would be best to collect isolates in a systematic manner from different regions where several pathotypes are known to coexist. A reasonably large sample size will be needed to obtain stronger inferences as to the possible distribution and spread of pathotypes within regions and across continents.

All P. t. f. teres isolates except MORZ-28 (Morocco) clustered into three groups at a distance of $13.8 \%$ based on their virulence phenotypes on the 25 differential hosts (Fig. 1). Generally, isolates with virulence on the same host genotypes were grouped into the same cluster. However, isolates of the same pathotype were not always related to each other. In an extreme example, isolates AUSKH565 (Australia) and MORZ-28 (Morocco) were both characterized as pathotype 0 , but they were not closely related. Obviously, these differences reflect the different criteria by which these isolates were typed. The designation of pathotypes is based on a somewhat arbitrary separation of HIR and LIR. In contrast, the cluster analysis reflects, in an unbiased way, the relatedness of isolates based on the full range of infection responses from 0 to 10 .

The probe ND218 detected 24 RFLP loci in $P$. $t$. f. teres and $P$. $t$. f. maculata in this study. It also provided a unique profile of restriction fragments for every isolate tested and would therefore be a useful tool for the DNA fingerprinting of $P$. teres isolates and population genetic studies.

The cluster analysis, without the weighting of RFLP band intensity, grouped two $P$. $t$. f. teres isolates from California, CA86-21-1 and CA86-72-2, together at the similarity level of 0.86 . These haplotypes could have been derived sexually from a common progenitor with limited variation. All other $P$. t. f. teres isolates were related at low genetic similarity levels ranging from 0 to 0.67 with cluster analysis. In general, the genetic distance between isolates of $P$. $t$. f. teres and $P$. $t$. f. maculata was no greater than among isolates within the same form; thus, no clear delineation could be resolved between the two subspecies. According to Smedegård-Petersen (1976), the capacity of $P$. teres to produce net or spot lesions on barley is determined by two independent allelic pairs. It is possible that $P$. $t$. f. maculata is a mutant form (McDonald 1967) of P. t. f. teres, because its characteristic of inducing spot-type symptoms on barley is inherited stably.

The sexual stage of $P$. teres has been reported in many regions of the world (reviewed in Shipton et al. 1973). However, the role of ascospores as primary inoculum in the epidemiology of net blotch is not clear (Mathre 1997). It is possible that ascospores play a more important role as a potential source of new virulence types than as the source of primary inoculum (Shipton et al. 1973). The low level of genetic relatedness revealed by the cluster analysis indicates that sexual recombination may be the primary source of variation in $P$. teres, but again this hypothesis must be tested using a larger number of isolates.

The broadly virulent pathotypes of $P$. $t$. f. teres found in this study suggest that when breeding for resistance, a group of isolates exhibiting different virulence spectra should be used in early generation tests. Barley genotypes of 'Rojo' (from the U.S.A.), 'Coast' (U.S.A.), CIho 9819 (Ethiopia), CIho 5791 (Ukraine), CIho 7584 (U.S.A.), CIho 5822 (Ukraine), ND B112 (U.S.A.), and FR 926-77 (U.S.A.) are from diverse geographic regions and were re- 
sistant to all of the isolates of $P$. $t$. f. teres and $P$. $t$. f. maculata used in this study. By using two or more of these genotypes as parents, barley breeders will be able to develop germplasm with broad-based resistance to both forms of P. teres.

\section{Acknowledgements}

This research was supported in part by the American Malting Barley Association.

\section{References}

Afanasenko, O.S., and Levitin, M.M. 1979. The population structure of the pathogen of net blotch of barley as regards its virulence. I. Identification of races. Mikol. Fitopatol. 13: 230-234.

Arabi, M.I., Barrault, G., Sarrafi, A., and Albertini, L. 1992. Variation in the resistance of barley cultivars and in the pathogenicity of Drechslera teres f. sp. maculata and D. teres f. sp. teres isolates from France. Plant Pathol. (Oxford), 41: 180-186.

Baltazar, M.B. 1990. Selection and characterization of genomic DNA clones of Pyrenophora teres and their application for disease diagnosis via the polymerase chain reaction (PCR). Ph.D. thesis, Montana State University, Bozeman, Mont.

Bockelman, H.E., Sharp, E.L., and Bjarko, M.E. 1983. Isolates of Pyrenophora teres from Montana and the Mediterranean region that produce spot-type lesions on barley. Plant Dis. 67: 696-697.

Ceniceros, F.G. 1990. Assigning genes conferring resistance to spot and net blotch in barley to a specific chromosome. Ph.D. thesis, North Dakota State University, Fargo, N.D.

Harrabi, M., and Kamel, A. 1990. Virulence spectrum to barley in some isolates of Pyrenophora teres from the Mediterranean region. Plant Dis. 74: 230-232.

Karki, C.B., and Sharp, E.L. 1986. Pathogenic variation in some isolates of Pyrenophora teres f. sp. maculata on barley. Plant Dis. 70: 684-687.

Khan, T.N. 1982. Occurrence and pathogenicity of Drechslera teres isolates causing spot-type symptoms on barley in Western Australia. Plant Dis. 66: 423-425.

Khan, T.N., and Boyd, W.J.R. 1969. Physiologic specialization in Drechslera teres. Aust. J. Biol. Sci. 22: 1229-1235.

Kohli, Y., Morrall, R.A.A., Anderson, J.A., and Kohn, L. 1992. Local and trans-Canadian clonal distribution of Sclerotinia sclerotiorum on canola. Phytopathology, 82: 875-880.

Leung, H., Nelson, R.J., and Leach, J.E. 1993. Population structure of plant pathogenic fungi and bacteria. Adv. Plant Pathol. 10: 157-205.

Majer, D., Mithen, R., Lewis, B.G., Vos, P., and Oliver, R.P. 1996. The use of AFLP fingerprinting for the detection of variation in fungi. Mycol. Res. 100: 1107-1111.

Mathre, D.E. 1997. Compendium of barley diseases. 2nd ed. American Phytopathological Society, St. Paul, Minn.

McDonald, W.C. 1967. Variability and the inheritance of morphological mutants in Pyrenophora teres. Phytopathology, 57: 747-755.

McDonald, B.A., and Martinez, J.P. 1990. DNA restriction fragment length polymorphisms among Mycosphaerella graminicola (anamorph Septoria tritici) isolates collected from a single wheat field. Phytopathology, 80: 1368-1373.
Milgroom, M.G., Lipari, S.E., and Powell, W.A. 1992. DNA fingerprinting and analysis of population structure in the chestnut blight fungus, Cryphonectria parasitica. Genetics, 131: 297-306.

Mueller, U.G., Lipari, S.E., and Milgroom, M.G. 1996. Amplified fragment length polymorphism (AFLP) fingerprinting of symbiotic fungi cultured by the fungus-growing ant Cyphomymex minutus. Mol. Ecol. 5: 119-122.

Murray, M.G., Lipari, S.E., and Powell, W.A. 1980. Rapid isolation of high molecular weight plant DNA. Nucleic Acids Res. 8: 4321-4325.

Nei, M., and Li, W.-H. 1979. Mathematical model for studying genetic variation in terms of restriction endonucleases. Proc. Natl. Acad. Sci. U.S.A. 76: 6269-5273.

Peever, T.L., and Milgroom, M.G. 1994. Genetic structure of Pyrenophora teres populations determined with amplified polymorphic DNA markers. Can. J. Bot. 72: 915-923.

Priestley, R.H., Batles, R.A., and Ryall, J. 1984. Identification of specific resistances against Puccinia striiformis (yellow rust) in winter wheat varieties. II. Use of cluster analysis. J. Natl. Inst. Agric. Bot. 16: 477-485.

Sambrook, J., Fritsch, E.F., and Maniatis, T. 1989. Molecular cloning: a laboratory manual. 2nd ed. Cold Spring Harbor Laboratory Press, Cold Spring Harbor, N.Y.

SAS Institute Inc. 1989. SAS/STAT user's guide, version 6. 4th ed. SAS Institute Inc., Cary, N.C.

Shipton, W.A., Khan, T.N., and Boyd, W.J.R. 1973. Net blotch of barley. Rev. Plant Pathol. 52: 269-290.

Singh, S. 1962. Biotic factors affecting barley net-blotch (Helminthosporium teres) epidemiology. Indian Phytopathol. 15: 195-202.

Slatkin, M. 1987. Gene flow and the geographic structure of natural populations. Science (Washington, D.C.), 236: 787-792.

Smedegård-Petersen, V. 1971. Pyrenophora teres f. maculata f. nov., and Pyrenophora teres f. teres on barley in Denmark. R. Vet.. Agric. Univ. Yearb. pp. 124-144.

Smedegård-Petersen, V. 1976. Pathogenesis and genetics of netspot blotch and leaf stripe of barley caused by Pyrenophora teres and Pyrenophora graminea. DSR Forlag, Copenhagen, Denmark.

Steffenson, B.J., and Webster, R.K. 1992. Pathotype diversity of Pyrenophora teres f. teres on barley. Phytopathology, 82: 170-177.

Steffenson, B.J., Hayes, P.M., and Kleinhofs, A. 1996. Genetics of seedling and adult plant resistance to net blotch (Pyrenophora teres $\mathrm{f}$. teres) and spot blotch (Cochliobolus sativus) in barley. Theor. Appl. Genet. 92: 552-558.

Tekauz, A. 1985. A numerical scale to classify reactions of barley to Pyrenophora teres. Can. J. Plant Pathol. 7: 170-177.

Tekauz, A. 1990. Characterization and distribution of pathogenic variation in Pyrenophora teres f. teres and P. teres f. maculata from western Canada. Can. J. Plant Pathol. 12: 141-148.

Tekauz, A., and Mills, J.T. 1974. New types of virulence in Pyrenophora teres in Canada. Can. J. Plant Sci. 54: 731-734.

Wilcoxson, R.D., Rasmusson, D.C., and Miles, M.R. 1990. Development of barley resistant to spot blotch and genetics of resistance. Plant Dis. 74: 207-210.

$\mathrm{Wu}$, H.-L. 1993. Molecular and virulence diversity in Pyrenophora teres Drechs. Ph.D. thesis, North Dakota State University, Fargo, N.D.

Zhong, S., and Steffenson, B.J. 2001. Virulence and molecular diversity in Cochliobolus sativus. Phytopathology, 91: 469-476. 